tration. There is no reason why it should not be also used in the form of spray in hæmoptysis, but I have had no experience of its use in this way. The dose may also be increased according to circumstances.

In the Irish IIospital Gazette I recorded some cases of hæmoptysis, \&c., in which liq. extract of ergot was used hypodermically with success. A combination of the ergot and pvrogallic acid will afford a very powerful means of arresting internal hæmorrhages.

Several standard works of reference have been examined without finding any record of the medicinal use of pyrogallic acid; but"there is nothing new under the sun."

\title{
IIYSTERO-EPILEPSY.
}

M. Charcot, in a paper read before the Société de Biologie, July 15 (Progrès Médical, July 27), shows that hystero-epilepsy, hysteria major, presents a type which, apart from secondary variations, remains always identically the same in its chief features. The attack can be divided into four periods preceded by an aura. The first stage is epileptoid, and does not differ from the comitial malady except in being susceptible of control by ovarian pressure or the electric current; it passes through a tonic state, to which succeed clonic spasms. After a temporary remission the period of contortions commences, at the time when the first hallucinations are produced. The third stage is that of passionate attitudes; the face expresses joy, terror, pleasure; the patient recalls her friends or remembers her enemies. In the last stage the patient, having come again to herself, is still under the influence of the temporary hallucinations; then little by little these latter phenomena disappear.-Iondon Medical Record, Nov. 15, 1878.

\section{PARACENTESIS ABDOMINIS BY GRADUAL DRAINAGE WITH A SINGLE FINE CANNULA.}

Dr. Reginald Southey, who last year suggested the use of a fine silver cannula to drain odematous limbs, has now adopted the same plan of treatment in cases of ascites, and with excellent results. In The Lancet, August, 1878, p. 176, a case is reported in which, during twenty-one hours, 11,400 cubic centimetres of clear fluid were evacuated by a fine capillary tube, inserted in the mesial line, midway between the umbilicus and pubes. In treatment, this mode of performing paracentesis leaves nothing to be desired; the tuto, cito, et jucundè are sufficiently fulfilled by it.-London Medical Record, Nov. 15, 1878. 
metallic applications of M. Burq (increase of muscular power, return of sensibility). It appears probable that magnets, which played a great part in the therapeutics of the last century, should be rehabilitated with more precise indications.

M. Romaine Vigouroux next reported two experiments upon patients with static electricity, using the dielectric machine of Carré. The patients having been placed on an insulated stool, under the influence of moderate discharges, the sensibility was found to return and to become generalised more rapidly than by any other means. This goes to confirm the role attributed by $\mathbf{M}$. Vigouroux to the electric tension in the phenomena produced in hysterical patients by metallic applications, continued currents, \&c. (Am. Journ. Nerv. and Ment. Dis.)

MODE OF REDUCING PROLAPSUS OF THE RECTCM.

In The IIospital Gazette, July 11th, 1878, Dr. J. C. Davis gives the following directions for reducing prolapsus of the rectum:-If the patient be a child, place it on its back, flex the thighs and legs at a right angle to the body; let the nurse or an assistant hold them in this position; wipe the mucus or other discharge from the prolapsed part; then take an old handkerchief, a piece of soft linen, or cotton rag, place it looseiy over the index finger and introduce it slowly into the rectum; the mucous membrane will adhere to the rag, and the part last descending will be the first to repass the sphineter. Carry the finger the full length of the rectum; then with two fingers of the left hand (one on each side) sustain the gut while withdrawing the finger. To remove the rag, keep up the counter-pressure with the fingers of the left hand, and pull gently, first on one side then on the other of the handkerchief or rag, and in this way remove it from the rectum. If the patient be other than a child, place him in the "Sims' position," and the same procedure will accomplish the object in view. The subsequent treatment, surgical or otherwise, will depend on the causes which have produced the disorder. Dr. Davis says that this method has proved eminently successful in his hands for more than a score of years. Its advantages are simplicity, facility, and rationality; there is no squeezing or brushing of the parts, hence little or no pain, unless the gut be inflamed.-London Medical Record, Nov. 15, 1878. 
note brought out on percussion depended upon which of the over-tones of the fundamental note was sounded. According to the conditions of the neighbouring pulmonary alvenli, sometimes one harmonic would vibrate and sometimes another, and the note of the harmonic wonld be lower or higher according to the tension of the alveolus. A further source of variation would be the enlargement of any of the alveoli.

DR. HARveY, in reply, said he was at one with Dr. Henry Kennedy in never having called the phenomenon in question compensatory emphysema. Gentlemen who upheld the idea that the note in question was due to compensatory emphysema asserted that in consequence of the lower part of the lung having become solidified the air that should have gone into it went into the upper part of the lung. In reply to Dr. MacSwiney, who had asked how it happened that in cases in which adhesions of the pleura were known to exist, a note of this sort had been heard in one part of the case and had afterwards disappeared, Dr. Harvey said that that was a condition into which he had not entered at all. What he had spoken of was simply compensatory emphysema as an explanation of conditions where they had nothing at all to do with pleural adhesions.

The Society then adjourned to December 4th.

\section{A NEW OPERATION FOR PHIMOSIS.}

BErsG struck by the inconvenience of the ordinary bleeding operation, M. Jude IIue (Le Progrès Mlédical) has proposed a section of the prepuce in the median line and on the dorsal surface, by means of the elastic ligature. For this purpose a needle, threaded with an elastic band, is passed between the prepuce and the gland until the bottom of the cul-de$s a c$ is reached. The prepuce is then transfixed, and two ends of the elastic are knotted at the free border of the prepuce. In ten days or a fortnight the ligature comes away and the operation is complete. M. Horteloup had invited M. Hue to operate upon patients in his hospital, and the results at first were not encouraging, as a good deal of pain resulted for 24 or 48 hours. When the patients were seen three months afterwards, the results were found to be very satisfactory, so that $M$. Horteloup recommends this simple method in cases of phimosis without hypertrophy of the prepuce, and where there is no inflammation or thickening of the integument, and he thinks this plan will be found of great service in children.-London Medical Record, Nov. 15, 1878. 
with good effect for that common and troublesome pain in females known as infra-mammary pain; it is also excellent for ovarian hyperzes. thesiæ, and many other forms of pain besides lumbago and sciatica, for which it is so commonly employed. Mr. Lennon's patient was able to go back to his work two days after having been "fired."

Mr. Gordon was equally successful in a much less promising casethat of the little boy, aged 13 , who was ill for two years with a chronic limited effusion in the cavity of the peritoneum, and whose scrotum had. become so odematous as to equal a cocoa-nut in size, and to cause painful chafing, by friction against his thighs. Mr. Gordon made four punctures with a lancet at each side of the raphe so judiciously that no untoward evernt happened. Coincidently with the subsidence of the genital œdema the ascites disappeared, the pain and swelling of the stomach departed, and he became able to walk about as well as ever. I particularly allude to these two matters to show you that the gentlemen in charge of cases have the fullest opportunities and encouragement to do with their own hands anything which is conducive to the welfare of the cases they take charge of.

BRONCHIAL CATARRH FROM BROMIDE OF POTASSIUM.

ONE of the occasional, unpleasant results of large or prolonged use of bromide of potassium is an obstinate bronchial catarrh, characterised by tenacious mucus and a "hard" cough. In the Memorabilien, Dr. G. Stille states that at times this may lead, in weak persons, to serious, even fatal results; and he recommends, on the appearance of this symptom, to suspend the drug. To counteract the other unpleasant symptoms, he has found the simultaneous exhibition of arsenic successful; but it was powerless against the catarrh.-Medical and Surgical Reporter, Oct. 12, 1878.

SUBCORACOLD DISLOCATION OF THE HUMERUS CAUSED BY SNEEZING.

Is The London Medical Record for November 15, 1878, Dr. Richard Neale remarks that Mr. J. Westmoreland, in The Lancet, August, 1878, p. 202, adds another to the list of injuries occasionally produced by sneezing. A publican, resting his left arm, during lateral extension, loosely on some spirit barrels, took a pinch of snuff from a friend, and sneezed violently, when his left shoulder slipped out of place. Dr. Neale observes that several cases of fracture of the ribs, and one case of dislocation of the crystalline lens, from sneezing, have been reported in the journals (vide Medical Digest, New Sydenham Society, section $598 ; 3$ ). 
and a high temperature in the United Kingdom. On the 21st this "fine weather" system broke up, and the weather underwent a complete change. At 8 a.m. of this day a large depression had its centre near the Hebrides, while another disturbance was fast approaching the S.W. of Ireland. Heavy rains, followed by a rapid fall of temperature, accompanied these disturbances. From this time to the end of the month an area of low atmospherical pressure occupied the position of the anticyclone noted above, and numerous subsidiary bourrasques travelled at first from W. to E. and afterwards from N.W. to S.E. across the British Islands, bringing in their wake keen polar winds and wintry weather. The mean temperature of the last eleven days was only $42.8^{\circ}$ in Dublin-being the coldest weather experienced in October since 1873. "Festooned" clouds were seen between 4 and 6 p.m. of the 5th. A lunar rainbow appeared at 9 p.m. of the $9 \mathrm{th}$. Solar halos were observed on the $16 \mathrm{th}$, 17 th, and 25th. Hail fell on the 24th, and at $330 \mathrm{p} . \mathrm{m}$. of the $26 \mathrm{th}$ several peals of thunder were heard, while there were occasional flashes of lightning on that evening and on the night of the 31st. Nearly an inch of rain ( 965 inch) fell on the .7 th.

\section{PERISCOPE.}

Edited by G. F. DufFeY, M.D., F.K.Q.C.P.

\section{RESEARCHES ON THE COLOLRING MatTER OF THE BLOOD.}

Sоме valuable contributions to our knowledge of the colouring matter of the blood have recently been made by Hoppe Seyler, to whom we owe so much of our information on this important subject. He finds that reduced hæmoglobin (or as he prefers to call it simply, hæmoglobin) is a test of the most extreme delicacy for free oxygen. If, by a suitable apparatus, a solution of hæmoglobin is brought into contact with an atmosphere containing such a small quantity of free oxygen that the tension of this gas at ordinary temperature equals only $1.5 \mathrm{~mm}$. of mercury, the appearance of the two well-known absorption bands in the solution manifests the presence of the oxygen. The tension of $1.5 \mathrm{~mm}$. IIg. corresponds, at ordinary atmospheric pressure, to a gaseous mixture which contains only 0.191 vols. per cent. of oxygen. Since 1 cc. of the gaseous mixture, and $0.5 \mathrm{cc}$. of the hæmoglobin solution suffice for the experiment, $0.002 \mathrm{cc}$. of oxygen can be detected by this method; or if the pressure be raised an atmosphere, as can be readily done, so minute a quantity as 1 cubic millimeter of oxygen can be made manifest.

If a solution of oxyhæmoglobin be sealed up in a tube, or other vessel, with only a small quantity of air, it is soon, by the process of putrefaction, 
deprived of its loosely-combined oxygen, and the spectroscope shows no longer the two bands of oxyhæmoglobin, but the single band of reduced hæmoglobin. In this condition it remains, without undergoing further change, for an indefinite time, completely resisting all putrefactive decomposition. Hæmoglobin, then, which is so readily decomposed by acids, alkalies, high temperature in presence of water, is unaffected by putrefaction, differing markedly from albumin, which in sealed tubes decomposes with formation of $\mathrm{CO}_{2}, \mathrm{NH}_{3}$, leucin, tyrosin, \&c. The action of the pancreatic ferment agrees with that of the putrefactive bacteria, and this agreement is borne out by the complete resistance which hæmoglobin offers to the action of trypsin, while the presence of free oxygen is not necessary for the action of this ferment on albumin. Carbonic oxide hæmoglobin resembles hæmoglobin in completely resisting the action of putrefaction or of pancreatic digestion. This peculiarity may be very useful for the detection of poisoning by $\mathrm{CO}$, and the blood from such cases may be preserved for years without undergoing change. Hæmoglobin may be used as a test for $\mathrm{CO}$, as for free oxygen. The degree of delicacy of the test has not yet been determined, but it must be even greater than in the case of oxygen.

A very interesting series of observations were made on the free oxygen of the secretions of the different glands, using a solution of hæmoglobin as the test. The solution and the secretion as it flowed from the duct were brought into contact, the air being excluded. The suliva of the parotid and the submaxillary glands contained free oxygen, and the spectroscope showed the formation in the experimental tube of oxyhæmoglobin, while the bile and the urine produced no change in the hrmoglobin, and consequently contained no free oxygen.

A series of analyses of the crystallised oxyhæmoglobin of the horse gave the following mean composition:-
C. $54 \cdot 87$
H. 6.97
N. $17 \cdot 31$
S. 0.65
Fe. $0 \cdot 47$

'The nitrogen, which was estimated by combustion with copper oxide, comes out much higher than in the former analyses of the hæmoglobin of the dog, guinea pig, goose, and squirrel. In these the estimation was made by the method of Will Varentrapp.

When oxyhemoglobin is acted on by ozone, by putrefaction in contact with the air, or by the pancreatic ferment, it undergoes a change which is shown by the appearance of an absorption band in the red part of the spectrum. The substance which gives this band was named by Hoppe Seyler methæmoglobin, but he was unable at the time to decide whether this was a separate body, or whether it was a mixture of albumin and 
hæmatin. Since then it has been supposed by various chemists that methæmoglobin was oxyhæmoglobin in a higher state of oxidation-in fact, a per-oxyhæmoglobin. No further proof, however, of this was adduced than its formation by oxidising agents. The fact that this substance is formed when arsenuretted hydrogen or sulphuretted hydrogen is passed through oxyhæmoglobin makes the oxidation theory very improbable, and recent observation has completely disproved this view. If a piece of palladium foil impregnated with hydrogen be brought into contact with a solution of oxyhæmoglobin, the colouring matter becomes converted into methæmoglobin. Here the hydrogen takes some of the oxygen to form water; hence, methæmoglobin must contain not more but less oxygen than oxyhæmoglobin. When a solution of methæmoglobin is submitted to putrefaction in a sealed tube, the band iu the red soon disappears, and the spectroscope shows hæmoglobin only. If with suitable precautions the tube be broken and the access of oxygen allowed, oxyhæmoglobin is again obtained and may be crystallised. It is not yet quite disproved, although very improbable, that from hæmatin and an albumin hæmoglobin can be reconstituted, but the relatively rapid transformation of methæmoglobin into hæmoglobin by reduction, distinguishes at once this body from hæmatin, which may be recognised by addition of ammonium sulphide to its solution, since in presence of an albumin hæmatin yields hæmochromogen, and methæmoglobin yields hæmoglobin. As the result of his former and more recent observations, Hoppe Seyler concludes that methæmoglobin is a compound which, even in the absence of oxygen, is split up by acids or alkalies into hæmatin and an albumin, and in which the iron exists in the condition of oxide; whilst in hæmochromogen, hæmoglobin, and oxyhæmoglobin it exists in the condition of suboxide. If by any influence, oxyhæmoglobin is split up, hæmochromogen, $\mathrm{O}_{2}$ and albumin result. The hamochromogen, like hydrated suboxide of iron, indigo white, and many other substances, is able to decompose the oxygen molecule, and oxidising itself with one atom of the molecule, sets the other free. This, being in the active condition, changes the oxyhæmoglobin, which still exists, into methæmoglobin. By this view is explained that in the coagulation of oxyhæmoglobin solution by heat, with or without the previous addition of acid, methæmoglobin is formed, as well as hæmatin (it is from this methæmoglobin, and not from the hæmatin, that the reconstruction of the hæmoglobin spoken of above probably takes place); and further, that in the splitting of oxybæmoglobin, fatty acids, as acetic and butyric acids, are formed.-Zeitschrift $f$. physiologische Chemie, I., 121, and II., 149.

J. M. P. 
TREATMENT OF SANGUINFOUS CEREBRAL APOPLEXY BY HYPODERMIC INJECTION OF ERGOTINE.

Dr. N. S. Foster observes that the utility of the subcutaneous injection for the exhibition of the active principle of ergot, on account of the rapidity and comparative certainty of its action, has been most successfully demonstrated in cases of post partum hæmorrhage. From the explanation given of its inducing contraction of the smaller arteries, and from the facility of its administration, especially in cases where swallowing is at least very difficult, he was led to use it in cases of cerebral apoplexy and also of hæmoptysis. He records two cases, in each of which the patient was attacked with symptoms characteristic of an apoplectic lesion, the coma gradually deepening. On the injection of ergotine into the arm the comatose state became stationary and the grave symptoms rapidly passed off. (Lancet, Sept. 21, 1878.)-Practitioner, October, 1878.

J. W. M.

a cystine calccles.

M. GatJor describes a case of cystine calculug in the Bulletin et Mémoires de la Société de Chirurgie, Nov. 3, 1878. The patient was a man aged twenty-five, who was admitted into the Val-de-Grâce on May 30th, 187i. The first symptoms of stone appeared in 1876. The calculus was removed by the prerectal incision, and the patient recovered in five weeks. The stone weighed 25 grammes ( 387 grains); it was ovoid in shape, of yellow colour, and had a rugose surface. Its greatest diameter was 44 centimetres (about $1 \frac{3}{4}$ inches). On section, it presented a homogeneous structure, without nucleus or strata; it was greasy to touch, and friable. Analysis showed it to be composed of cystine, with traces of phosplate and sulphate of lime, mucus, and fatty matter.-London Medical Record, Nov. $15,1878$.

\section{NEW PREPARATIONS AND SCIENTIFIC INVENTIONS.}

Aperient Fruit Lozenges. Prepared from the bark of the Rhamnus frangula by H. C. Baudon \& Son, Fdinburgh.

These lozenges are extremely palatable sweetmeats, prepared from the bark of the black alder, Rhamnus frangula. They appear to be very mild in action, and the preparation now introduced is likely to prove satisfactory. 